\title{
Women Educational Leaders in Principalship: Exploring the Lived Experiences of Women Heading Primary Schools in Côte d'Ivoire
}

\author{
Rassidy Oyeniran \\ Correspondence: Rassidy Oyeniran, Faculty of Education, Beijing Normal University, International and Comparative \\ Education Research Institution 19 Xin Jie Kou Wai Street, Beijing 100875, P.R. China.
}

Received: March 23, 2018

doi:10.11114/ijce.v1i1.3209

\author{
Accepted: April 11, $2018 \quad$ Online Published: April 13, 2018
}

URL: https://doi.org/10.11114/ijce.v1i1.3209

\begin{abstract}
In Côte d'Ivoire, the situation of women in positions of power remains a sensitive and controversial issue. Women are mostly subjected to preconceptions that place them in challenging situations. The study sought to explore the experiences of women primary school principals, and to examine the hindrances that these women leaders encounter. Using mixed method approach, 11 women principals were purposefully sampled from the research field comprised of 11 primary schools located in Abidjan. The questionnaire and the semi-structured interview were utilized as tools to gather data. Findings revealed that women principals have hidden talents and competencies, as they perform in an ethical manner using the transformational style of leadership. Yet, as showed in the results, women principals experience a number of challenges and hurdles that stand in their pathways or occur when performing their leadership roles. The current study advocates getting rid of unnecessary and harmful prejudices that prevent women from moving up in order to allow them to express their inner potential. Besides, this study suggests a critical way of thinking with a view to promoting women in educational leadership positions. There is a need to empower women not only by bridging the gap that exists between men and women, but also for the welfare of students, especially those with special needs, because every schoolchild regardless his or her family background has the right to succeed in his or her learning process according to the principle of equity, universally recognized.
\end{abstract}

Keywords: women principals, leadership, challenges, talents, Côte d'Ivoire

\section{Introduction}

Since its independence, Côte d'Ivoire has ratified various international and regional conventions with regard to equity in dignity and rights of all human beings. Besides, the principle of equality between women and men is enclosed in Côte d'Ivoire second Constitution ratified on July 23, 2000. Ivorian Constitution forbids all forms of torture, physical and moral violence, mutilations and humiliation towards women. Moreover, since the International Conference on the Population and the Development of Cairo in 1994 and the Beijing Conference in 1995 the participation of women in politics has been reinforced with a firm engagement. Furthermore, the 17 Sustainable Development Goals (SDGs) and their 169 targets, whose aim is to build on the Millennium Development Goals (MDGs) and complete what these MGDs did not achieve, were considered as the promise made by the Ivorian government (UN, 2017) to empower Ivorian women. Through the goals 4 and 5, SDGs intend to ensure inclusive and equitable quality education and promote lifelong learning opportunities for all, and achieve gender equality and empower all women and girls.

In all these actions and policies, the key issues focus on the elimination of negative economic, social, political, cultural and structural practices that obstruct equality and equity between woman and man. The promotion of equal opportunities for both men and women in leadership positions is emphasized as well. Although stipulated within laws and in statutes of political parties, the promotion of women to leadership positions is not reflected within the political and social context. Actually, these attempts do not change the situation of women, especially in education where women are still facing challenges and are under-represented in leadership positions. In spite of meritocratic discourses, national initiatives and affirmative actions on gender equality, women have limited access to senior levels of educational management in Côte d'Ivoire (Akpaka, 2007). Actually, gender issues, stereotypical perceptions and discrimination bring about problematic situations in educational spheres and remain a controversial subject along with women leadership. Despite a number of efforts made by the authorities in recent years to empower women, men are still largely privileged to lead most educational institutions. Indeed, in Ivorian societies, women are generally confined to the lower positions in educational work settings. Sociocultural heritage and organizational barriers are some of the factors that 
maintain women in inferior steps and affect their leadership potential. (Moreau, 2014). This is obviously not conducive to gender equality. In Ivorian context, the dominant traditional ideology related to patriarchal culture, which is profoundly entrenched amongst the individuals, presupposes subordination of women, often together with the exclusion of the public sphere and in particular, the educational settings. The stereotyping perceptions often led many women to lack confidence. However, women themselves are building a perception that they sometimes are afraid to engage in public or private activities because of the social norms and cultural beliefs (Andela, Escandon, Garlo \& Kamungi (2008). Yet, academic studies have found that women would be worthy leaders, which may help to address in some persistent issues in Ivorian primary schools, and indirectly contribute to schools advancement.

\subsection{Purpose of the Study}

The purpose of this study was to explore and understand, through their lived experiences, the major challenges faced by women in school leadership positions, with specific reference to Abidjan, a District in Côte d'Ivoire. The research was an opportunity to raise the unheard voices of women school principals and to help eliminate socio-cultural and institutional barriers for the advancement of women in school leadership positions. This study also sought to contribute to the growing body of knowledge in the field of female leadership practices by expanding the reality of lived experiences and enriching the research methodology regarding the study of women educational leaders. Furthermore, the findings of this study will increase the limited literature available in Ivorian women lived experiences in educational leadership positions.

\subsection{Research Questions}

- How women principals, as leaders, perform their leadership roles?

- What are the major barriers that hinder women in school leadership positions?

\section{Literature}

\subsection{Key Concepts}

The definitions of the key concepts concern school principal, principalship and leadership concept and these are the main important words that need to be clarified to get a better understanding of the context where the study was conducted.

\subsubsection{School Principal}

A school principal is an educator who has executive authority for a school ${ }^{1}$. Invariably, the principal is called headmaster, school head, or head teacher. As a school leader, the principal is responsible for the overall operation of a school. In Ivorian context, the head of primary, middle and secondary schools is called principal or director of the school. As such, he or she is the person having a leading or starring role in a performance, and the person having prime responsibility for an obligation as distinguished from one who acts as surety or as an endorser ${ }^{2}$.

\subsubsection{Principalship}

From the above definition, it can be clearly understood that the principalship is, thus, the position holding by the principal whose role or responsibility is to manage financial operations, infrastructure maintenance, coordination of the instructional program, student scheduling, internal and external relations, school policy with regard to discipline, and other overall school stuff and issues. Principals are also responsible for facilitating their school's interactions with parents and others in the school community. This responsibility includes working with parents when disciplinary issues arise, when students are not succeeding academically, and when parents have concerns (Principal, School, 2002)

\subsubsection{Leadership Concept}

Talking about leadership, Mintzberg (1990) author of numerous books on management and leadership admitted that it is difficult to define leadership in simple words. Nevertheless, several authors (Bergeron, 2006; Hallinger \& Heck, 1998; Riley \& Louis, 2000) attempted a slight definition and nature of leadership based on their experiences. For example, Bergeron (2006) assumed that

It is quite surprising that, despite a large amount of work on the subject and managers, researchers still do not know almost anything about the essence of leadership, of the reasons why some people lead and other people follow (...) the notion of leadership remains enigmatic to us; a catch-like charisma attests our ignorance". (p. 417)

\footnotetext{
${ }^{1}$ https://www.thefreedictionary.com/school+principal

${ }^{2}$ https://www.thefreedictionary.com/principalship
} 
Academic writers just consider leadership as the function of guiding and influencing others, and get them to achieve ambitious goals. For other scholars, the leader is a coach that trains individuals and assist them in performing their duties (Bergeron, 2006) within a particular context and a workplace setting. Since leadership refers to a process and influence, it implies interacting with people and followers. However, there is no interaction without difficulties, tensions and challenges. For women, leading organisations like primary schools might be harder to move towards high level (professional and social); and dealing with people may be a constant challenge on their pathway due to some obstacles like stereotypes, cultural, traditional, and social barriers. For a very long time, Ivorian women have been perceived socially and culturally as individuals, whose place is house raising and taking care of children and manage homes. Social habit has conditioned people to believe that women are less competent than men at holding leadership positions that led women to underestimate their own abilities and perceive themselves as less skilful and passive in leadership, as they consider themselves to have a lower level of acceptance than men whatever education and skills they possess.

\subsection{Women Leaders in Educational Settings}

Speaking of the role of school heads at a seminar3 on improving Ivorian educational system, the General Inspector (G. I) of Ministry of Education invited all educational stakeholders to reflect on the following question: "What kind of leadership can improve the quality and the performance of our schools?". A deep analysis of this question leads to looking at the school management issue with a careful consideration to the leadership models and styles as well as the leader's personality. In order words, the Chief Executive Officer (G. I) was rising the question of the characteristics profile of leaders that are useful and suitable for the Ivorian schools' performance, especially the students' academic achievement. As a response to the GI's question, it can be postulated that women leadership seems appropriate in the context of Côte d'Ivoire education. Actually, in the field of education, studies have revealed that women play valuable roles as leaders that bring benefits to the schools in terms of improvement and performance (Kele \& Pietersen, 2015; Héon, Lapointe \& Langlois 2007; Hallinger \& Heck, 1998; Gupton, 2009). Furthermore, the academic literature has consistently found that women do not behave in the same way as men. One might wonder if women use their influence in the same way as men and if their leadership styles produce different effects depending on the situations, the type of organization, and the followers. This question is important because it will help to understand why several studies found that women's leadership is perceived as effective in social organizations like the schools. Yet women do not easily reach leadership positions in their professional lives and that is the common trend in the world, specifically in African societies and particularly in Ivorian Context.

Besides, despite the existence of affirmative actions and numerous regional and international conventions ratified by the Ivorian Government to promote and achieve gender equality and equity, Ivorian women in educational leadership still experience challenges, including personal, professional and structural obstacles. Beyond challenging situations, women principals strive to manage by keeping in mind that pupils deserved consideration.

\subsection{Constraints and Barriers to Women's Leadership in the Ivorian Context}

Despite the evolution of society and commitment to gender equality, men are still largely privileged to lead organizations. In spite of meritocratic discourse, gender issues limit women's access to senior levels of management. In traditional African society, especially Ivorian society, women occupy a second place with limited freedom of expression, especially in public life since they could not speak in public in the presence of men. Her family upbringing kept her in that dependency. The cultural beliefs against women often leads many women to lack of assertiveness. Women themselves have developed a perception that they are sometimes afraid to engage in public or private activities because of the negative stereotypes that the community holds against them. They transmit generation to generation this perception, regardless their level of education. This situation is obviously not conducive to their efforts for equality between them and men. In Côte d'Ivoire, cultural traditions and professional practices have generally marked to be against women and accord them an inferior status. Similarly, cultures and custom widely consolidate cultural gender biases against women, which is compounded by gender stereotypes that persist and vary greatly with location and social context. Very often situations of women having leadership positions are related to the constraints linked to their status and some sociocultural barriers. For example, lack of confidence and lack of ambition, the persistence of discriminatory laws against women, the discrimination and relation of unbalanced forces between the spouses in the family (inequality of work and responsibilities within the household) seem to be considered as major constraints (UNESCO, 2002).

Traditionally, African women have specific roles reserved for them in society. In addition to children raising, the woman is responsible for household labour, care of family and education of children. Reconcile family life with the career is not

\footnotetext{
${ }^{3}$ This event took place at the beginning of the 2014-2015 school year, a meeting that attended school heads and a representative number of actors in the education system. On this occasion, the GI discussed the concerns of the Ivorian education emphasizing the issue of the school performance.
} 
always easy for women especially when they assume leadership positions. In Africa, especially in Ivorian context women face difficulties that are based on the social responsibility of the domestic field and reconciling the career and family life. They enjoy less power than their men counterparts do. Indeed, the situation of women in positions of power remains a controversial topic in Africa, specifically in the Côte d'Ivoire, where gender bias obstruct women's empowerment for reasons related mainly to the cultural and structural barriers and the society's stereotypes in general. Eagly Johannessen-Schmidt and Van Engen, in their study conducted in 2003 using a meta-analysis of 45 studies on transformational leadership styles, transactional or laissez-faire, were able to highlight the difference in leadership and management styles of men and women: first, women are more likely to adopt transformational management styles than men are. Moreover, they are more likely than the latter to use a mode of rewards when engaging in a transactional leadership style. Second, their findings revealed that, men are more likely to use a laissez-faire style than women are. Moreover, they are more likely than the latter to emphasize the problems or passively wait for problems befall when adopting a transactional style.

\section{Method}

The current study adopted the mixed methods whereby both qualitative and quantitative data were gathered and analysed as well (Creswell, 2012). This exploratory study employed both method approaches as the experiences and perceptions of the participants are significant. According to Conger (1998) leadership is a topic that can best be explored using qualitative research, due to the nebulous nature of leadership. The researcher used the inductive approach as it relates to a limited number of samples (11 schools); as stressed Miles and Huberman (2003), it is possible to develop a model from an inductive approach. Therefore, inductive approach allowed the researcher to use the observation that aims to generate meanings and relationships to form models (Saunders, Lewis \& Thornhill, 2012). As this study is concerned with learning from women principals' experiences, patterns, resemblances and regularities in experiences are observed in order to reach conclusions (Bernard, 2011).

\subsection{Research Field}

The research field comprises 11 primary schools located in the South Côte d'Ivoire, which is the economic Capital city (Abidjan). This area was selected for two reasons. First, the researcher opted for Abidjan zone as he resides and works there. Thus, the schools were selected from Abidjan, as Bogdan and Biklen (1998) strongly suggested to select a site for research that is closed to the researcher. Second, being a bid town Abidjan City homes most schools are led by women. Out of 1401 principals leading the public primary schools in Côte D'Ivoire there are 379 women in Abidjan, or 25\% (MoE, 2017). Therefore, it is quite likely to find women participants who have profiles that fit the purposeful sampling criteria designed for the current study.

\subsection{Sampling Approach}

The researcher used purposive sampling to get appropriate participating schools. The need to sample is one that is almost invariably encountered in qualitative research (Bryman, 2008). For the recruitment, both purposeful sampling procedure and criteria sampling methods were employed to select the sample for the study. Purposive sampling is a non-probability form of sampling and its goal is to sample cases or participants in a strategic way so that those sampled are relevant to the research questions that are being formulated (Bryman, 2008). Combining sampling strategies may be more appropriate to the aims of implementation research and more consistent with recent developments in quantitative methods (Palinkas, Horwitz, Green, Wisdom, Duan, \& Hoagwood, 2013). The researcher selected the participants according to criteria of eligibility to participate because the selection should be based on criteria relevant to the topic, which the researcher wishes to examine, and based on the intention of the study. A total number of 11 women principals participants were selected (each woman from each school), answered the questionnaire (open-ended questions), and have been interviewed (because of their experience in the principalship) as well.

These women principals were seen as participants who could provide rich information in contextual detail and individuals' lived experiences, as they are the ones likely to be experiencing life's issues in the principalship. More specifically, the researcher selected participants who have a certain charisma and have been employed as teacher or principal for a minimum five (5) years and whose age varies between 40 and over 50 years and who have professional experience of at least 5 years in teaching position or in the domain of education overall. Two factors were considered: the age and the work experience (duration or length of time as principal) of participants. This sample was representative (whenever there is saturation collected responses during interviews) accepting that qualitative research focuses more on the content (perception, feeling, attitudes, behaviours, practices, styles) than the number of interviewees.

It important to indicate that, because of ethical considerations, women principals in this study are identified with pseudonyms. For each of them, the pseudonym is WP (which means woman principal), and numbers are associated to their pseudonyms. Thus, woman principal, number 1 was identified as WP1. All this intends to ensure the confidentiality of these women educational leaders. 


\subsection{Instrument}

The study used the questionnaire to gather data from these women leaders, and then the semi-structured interview to delve into their principalship and their milieu, to examine the social role, the social structure and gender stereotypes that hinder women principals in their principalship in order to contribute to the social change and facilitate the structural change. Using phenomenological approach the researcher gained access to women's experiences and capture their perceptions of leadership as principals, from their own perspectives (Muzvidziwa, 2014).These women principals have had the opportunity to tell their stories in a narrative way. Direct observation was also used in this study.

As an "outsider" he watched and recorded what was going on in the schools under study (Creswell, 2013; Bryman, 2008). The Over visits to the schools and during the four months the researcher spent within the schools, he observed what was going on. By choosing direct observations (Yin, 2014), the study intended to further gain insights and to develop his understanding of what the principalship is about and how it works. The researcher paid much further attention to details in the school environment and social and structural interactions. He observed the schools' structure and environment; he also watched how women principals acted, reacted and interacted with teachers, students and other people within schools; focusing on women principals' practices of management and leadership styles to understand things from his own perspective (Backer, 2006). He observed how the principals received, met and talked to the visitors, including parents and officers.

\subsection{Procedure and Data Analysis}

The current study aims to identify in two schools how women primary school principals experience the multiples hindrances, and how these women succeed despite stereotypes, discrimination, inequity, structural obstacles and other issues they face within and outside of schools. Quantitative data were gathered from questionnaires while qualitative data were collected through semi-structured interviews with the participants. The study was designed to target their opinions, beliefs, and perceptions about their past and current experiences as leaders. The responses of the interviews were recorded using a voice recorder. This investigation took two weeks and one day. Participants were identified under codes to ensure the confidentiality. The qualitative data were coded systematically according to specific themes and then analysed to address the research questions. Data audio-recorded was transcribed by categorizing the meanings. Each interview transcription and the content extracted from the questionnaire were reviewed individually with themes emerging based on each individual's answers.

The data were reported using thick description and verbatim quotations. Transcribed verbatim was gathered and grouped and regrouped according to similarities and differences then analysed qualitatively. In so doing, the researcher reviewed the transcripts to discover any meanings or emerging themes, refining of categories and themes, identifying how the themes fit within the theoretical framework and literature and identifying quotes that highlight key theme (Akerlind, 2005).Quantitative data was analysed using SPSS (Last version.22) while qualitative data were analysed employing NVIVO software. Findings are presented in tables and verbatim accounts and quotations.

\section{Findings and Discussion}

In addition to demographic information about the participants, this study discusses two emergent themes that came out of the data. These are leadership styles and practices, and major issues that women principals experience in their principalship. Through the interviews, the participants expressed their personal and professional experiences as well as their self-perceptions regarding their leadership styles. The narrative style was used to gather the stories of participants of leadership. The following subsection, first, presents the women informants' portraits, which include their age, teaching and principalship experiences, marital status and number of children. 


\subsection{Demographic Profile and Information of Participants}

Table 1. Selected women summary information

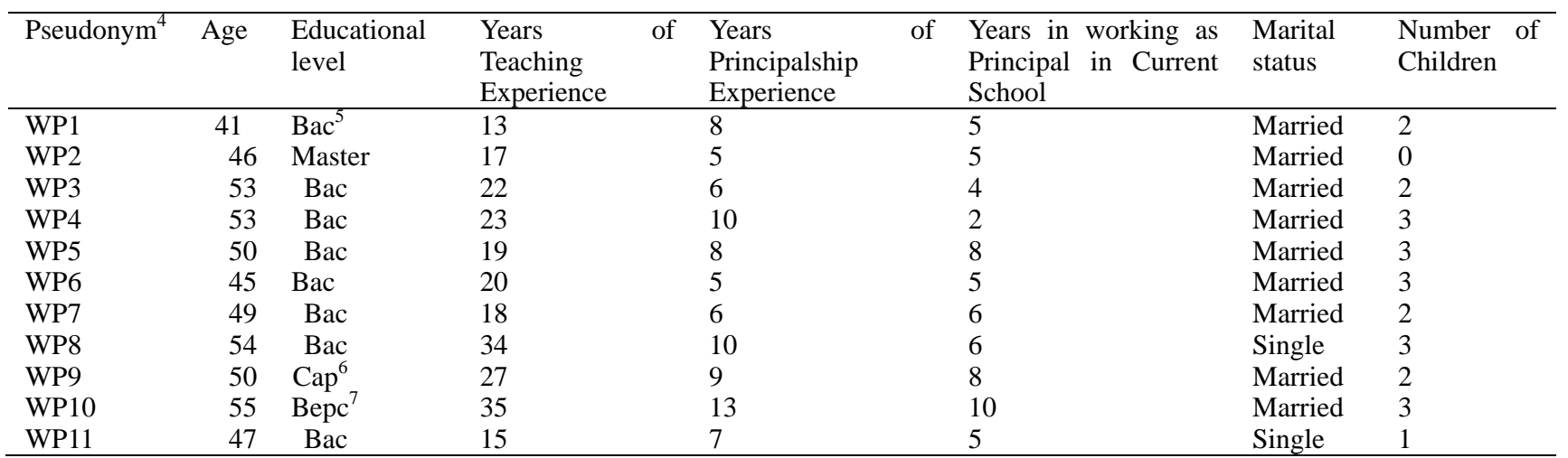

The above table shows that all of the informants were in the age ranges of 41 to 55 years. This shows that the findings of this research came from mature women, and all of them were quite experienced in the teaching and principalship role as illustrated. Besides, the same table shows that there is a woman (WP10, pseudonym) who is the oldest among the participant, and she has the longest professional experience as a teacher and school principal, which means that she has had a lot more career experience compared to other women principals. This was a result of the purposive sampling. This helped to capture the differences that exist between each woman lived experience, as everyone experiences life (personal and professional) differently. It is important to note that this came out of their interviews and narrations. She (WP 10) provided the researcher with rich information relevant to the study and anecdotes that marked her past experience and career path. Among these women leaders, one (WP2, pseudonym) holds a Master degree, but she has no chid. However, it does not exempt her from home tasks, as she is a married woman and she has to take care of her spouse and remains a wife as well according to her tribe's customs.

The above table also presents two women (WP8 \& WP11, pseudonyms) who are single; yet, they have children, which means they are responsible for their education and well-being since they raised them and continue to bring them up. Thus, being alone and feeding and educating their kids might have produced various forms of experiences and built up their personality. As shown in the table, the respondents' experience in leadership positions ranged from 5 years up to 13 years. Therefore, it can be assumed that most of these women would have experienced the leadership of a woman at some point in time during their professional experience. This, therefore, gave actual and valuable information from more experienced participants who have more information from their personal and professional experience.

Table 2. Major issues experienced by women primary school principals

\begin{tabular}{lll}
\hline Responses & & \\
\hline Majors issues & $\begin{array}{l}\text { Frequency } \\
\text { Val. }(\mathbf{N = 1 1 )}\end{array}$ & Percentage (\%) \\
\hline Social roles and gender stereotypes & - & - \\
1. Negatives attitudes of people & 9 & $\mathbf{8 1 \%}$ \\
2. Patriarchal leadership structure and mindset & 7 & $\mathbf{6 3 . 6 \%}$ \\
Issue of balancing work responsibilities and family duties & 4 & $36.3 \%$ \\
Lack of financial and material resources & 9 & $\mathbf{8 1 \%}$ \\
Issue of network & 8 & $\mathbf{7 2 . 7 \%}$ \\
Being powerless in decision-making & 6 & $54,54 \%$ \\
Marginalization & 4 & $36.3 \%$ \\
Lower appointment opportunities to advance & 4 & $36.3 \%$ \\
Lack of confidence & 2 & $18.1 \%$ \\
\hline
\end{tabular}

\subsection{Leadership Styles and Practices}

This subsection discussed concerns around the following factors that affected women principals in the study: Family Education Influences Handling conflicts and problems within schools Focusing on Instruction: tendency of transformational style of leadership

\footnotetext{
${ }^{4}$ Pseudonyms were used in the study to protect the privacy of the participants.

${ }^{5}$ Baccalaureate [The degree before joining College/University in Côte d'Ivoire]

${ }^{6} \mathrm{CAP}$ is also a certificate from vocational school the equivalent of BEPC in general high school

${ }^{7}$ Junior Secondary School Certificate Examinations
} 


\subsubsection{Family Education Influences}

Listening to the stories from these women principals, the researcher realized that the leadership styles of these women stem from their family education and past experiences. Actually, women's childhood life, past experiences, socialization and their self-perception in the society shaped in certain ways their personalities, their leadership styles and their resistance to the difficulties and structural obstacles. Geographical settings, traditional and religious practices in which they have been brought up also shaped their experiences. The findings revealed that women principals in this study perform their principalship roles by attaching great importance to collaboration, as they were team-oriented, working in an inclusive way. Sharing their power: leadership with collaboration seemed to be another tendency of women principals in this study. WP3 (pseudonym) stated:

My door is always open for teachers and students. I discuss everything concerning the school with my teachers that is why they approach me easily. I am very attentive to everyone and listening is my priority (...) I emphasize intellectual dialogue and critical thinking, all this is creates a positive working environment in the teamwork.

WP4 stated:

Here nobody left behind when it's come to reflect on school matters. We are informed about any school business; we always work together the principal make decisions based on our common discussion. This, consequently, fosters trust and confidence, which is important in human relationship everywhere, including the school.

The above description of women's style is well documented in the literature with various and different perspectives. Actually, women leaders in education are perceived to have an inclusive and participatory inclination. Baudoux (2002) and Shakeshaft (2006), after analyzing gender leadership in education, found that women leaders would foster cooperation and human relations, manage collegially, with a notion of power rather than power itself, and would be inclined to innovate. Thus, women would focus on the well-being of individuals and groups, foster participation and cooperation, favor collegiate relationships, and innovate easily, while men would aim for results, promote competition, prioritize reporting and have a traditional vision, which seems unlikely to innovate. In these studies, women were more likely than men to perform their roles in such ways that remind the transformational leadership style and inclusive approach. Yet, results of another study conducted by Funk (2015) in Brazilian municipalities suggested that women leaders are not inherently more participatory than men; rather, the decision to initiate participation in a certain policy area appears to be a strategic choice. These findings revealed that contrary to preconceptions and gender stereotypes men are more likely to adopt participatory councils for women's rights, children's rights, and health care, while women are more likely to adopt a council for sports. Besides, Walker and Woehr (2014) and Paustian-Underdahl, Gartzia and Van Engen (2012) have shown various results on the differences in leadership approaches between women and men. Furthermore, Kloot, (2004) concluded that the women experienced a masculine-oriented management culture, with little experience of feminine management values. Kloot stressed that the women and the men had different perceptions of management roles and different perceptions of alternative job opportunities.

In the present study, the findings revealed that women place a high value on ethical considerations, such as social justice, equity. According to Shakeshaft (2006), women leaders work for social justice and desire to change things. Besides, the findings indicate that women principals in this study supportive, attentive and concerned for the social-emotional state of their staff, these women principals displayed what Gilligan (1982) named an 'ethic of care'.

For example, WP10 felt that

The head of the school should know how to run the school group, having in mind that the school comprises women and men who may act differently according to their feelings, opinions, and perceptions, and react with regard to the circumstances, events or time (...). To get their full potential it's necessary to care of them and let them express what they abilities.

From the above statements, that women principal evoked a profound attention that women generally attach to human beings. This finding gets support from Gilligan (1982) who underlined the importance of the moral attitude of women. Indeed, Gilligan's perspective of ethics of care proposes that relationships and the caring for others influence women's morality. 'women's sense of integrity appears to be entwined with an ethic of care so that to see themselves as women is to see themselves in a relationship of connection'(Gilligan, 1982, p. 351).

\subsubsection{Handling Conflicts and Problems Within Schools}

The findings pointed out how women leaders in this research handle problems within schools. A school is a place where diverse people interact (school board, parents, teachers, visitors, community members). These interactions bring about a number of actions and reactions, including conflicts, tensions and grievances; that is why the principal needs to be proactive and efficient in solving problems. WP10 stressed that having problem-solving skills would strengthen the leadership style. As an observer, the researcher has noted that women principals possess problem-solving skills, as they 
were able to handle and solve successfully serious issues that occurred (conflicts, complaints, problems, tensions). When asked how she goes about conflicts and tensions in her school, WP10's response was,

I always try to be proactive before conflicts or tension come about I used to give room for dialogue. I also allow my staff members to express themselves freely (...) when a misunderstanding rises ...among members, I make my judgement based on our fraternity, I used soft words and I emphasize communication. Last year, I have been dealing with cases of conflicts between parents and teachers, and between teacher and teacher (...) At times, it is not to reconcile people who are in conflict when it is not overt, but I always try my best and mostly my methods work.

Al-Jaradat and Zaid-Alkilani (2015) indicated that the most successful leadership practices of the school principals in solving the school problems were as per the following order: student's problem solving, teachers' problem solving, and school environment and supply problem solving, respectively. In her study, Mberia (2017) further stressed that women leaders are perceived to be possessing positive leadership qualities including honesty and conflict resolution, that they are peacemakers and competent decision makers.

\subsubsection{Tendency of Transformational Style of Leadership}

Women in this study emphasized instruction, and the dimensions of transformational leadership appear more appropriate to describe these women's leadership style, as they lead in such a way that inspires and motivates their staff members. As a model, these women leaders gained teachers' confidence and trust, as they inspire respect and commitment from their teachers. The transformational leader uses his or her inspiration to communicate high expectations; he or she uses symbols to focus efforts and expresses important purposes in simple ways to achieve these goals and introduce change to execute them (Bass, 1985; Eagly, 2007). Strong relationships between leading, learning, and teaching likely enhance the quality of teaching and student performance. Indeed, the active collaboration around instructional matters between principals and teachers has a greater chance to influence positively the quality of teaching and student achievement/outcomes. However, Marks and Printy (2003) found that transformational leadership is a necessary but insufficient condition for instructional leadership. When transformational and shared instructional leadership coexist in an integrated form of leadership, the influence on school performance, measured by the quality of its pedagogy and the achievement of its students, is substantial. Hallinger (2008) mentioned that "female principals at all levels exercise more active instructional leadership than their male counterparts" (p. 31). WP1 revealed,

Whenever I am available I am very much focused on teamwork and staff development. I think it is a feminine characteristic to worry about well-being people in their work. I spend time accompanying teachers to make sure that the tasks objectives are clear while being very demanding, but when a difficulty arises, I'm right there to help.

Being transformational reflects in women principals' behaviours and in what they value the most. In the same vein, WP5's method is to encourage teachers and congratulate them and students as necessary as possible. She commented: The mission of the school is to put people in a good mood. It is useless to lead with dictatorial manner. You have to manage without putting pressure on your staff. We must avoid pressure at school; we are already under pressure with our job. It is necessary to give an account, to fill the notebooks, the documents and to have one's documents up to date. In particular, myself, family duties also push pressure on me. That why I believe that we must also allow others to show their maturity. On the other hand, these women leaders operate in an ethical manner, including social justice and equity as demonstrated in their actions. WP3 elaborated,

Here we have a lot of children who are from low-income families and poor social economic backgrounds. There some whose parents were divorced or lived separated for a long time (....) I remember that a couple days ago the school received 18 supplies from Ministry. Because of the big number of pupils in the school, the distribution was quite difficult to make. So, the principal just shared among those students coming from the very poor family background. The rest was distributed to those who were from the middle background and other students. I think that was an evidence of equity and justice from our principals.

From the above quote, it can be noted that women tend to devote more time than their colleague men to educational activities do. This aspect of performing a variety of tasks has been observed in WP2's practices as she used to supervise the school activities and learning to make sure that everything is done correctly, safely and on time. The educational activities (EA) concern all the activities related directly or indirectly to the support, mentoring, the help for students' learning activities, including, among others, the management of teaching, supervision, and professional development of teaching staff that produce a climate that enriches student learning (Brassard, Cloutier, De Saedeleer, Corriveau, Fortin, Gélinas \& Savoie-Zajc, 2004). This is also in accordance with St-Germain (2013)'s study that revealed that women principals devote more time to school activities and students than the men principals do, and women principals are more devoted to teaching tasks, as they are more focused on EA-oriented tasks. Levandowski (1977 as cited by Baudoux, 1987) also stated that at the primary schools, women principals work more with students and spend more time than their male colleagues do in solving problems and conflicts between parents and their children. Growe and Montgomery (2000) 
further underlined that women principals are more likely to interact with their staff and spend more time in the classroom or with teachers discussing the academic and curricular areas of instruction.

Findings of this study reveal that most women principals utilized identical terms to define their styles: decision-making in cooperation with their teams, collaboration, listening, the concept of team, participation, dialogue, support, caring. They largely referred to the need to "do together" or jointly with their collaborators. They also desired to operate within a positive environment with humanistic and respectful manner. They were more like leaders. They were very much attached to values such as social justice, solidarity, and equality, honesty. They also indicate that it is by showing the example that they transmit the values of work to their teams. They acted, as they want their people to act. In their remarks, they stand out; especially through the links, they create with their teams. Thus, it seemed women principals' tendencies in this study referred to the "transformational" management stated by Bass $(1985 ; 1990)$. It seemed that in order to define themselves, they draw on their references, but also in comparison with the masculine management, whether they have lived directly or seen around them. From that description, it is safe to state that women showed an evidence of equity and social justice, which is appreciated by most teachers. Actually, women principals in this study looked at leadership from individualistic to collective perspective, as if they carried a "social and inclusive" conception of leadership. They are more relationship-oriented, and they focus much on improving student outcomes. WP8 confessed that "I try to manage by paying attention to my all staff members and every detail within the school because they are all important". She used to create a less hierarchical rapport in the school, as she committed herself and she always tries to get close to her teachers and students. WP8 also is opened to any kind of comments and suggestions. She stated, "I emphasize relationships with the teachers because they need to be considered as good workers". WP8 seems to pay attention to individualized consideration, as she believes that "teachers share and accept your vision when you are closed to them and you do your best to support and help them as much as possible". Leithwood (2012) acknowledged that leadership effects on students learning are mostly indirect. For him, this means that successful school leaders have direct and positive influences on learning conditions in the school and classroom, which in turn improve the learning of students.

Other conditions leaders are able to influence such as school climate, school culture, however, have a direct and powerful impact on student learning (ibid.). This first opening part sets the problematic up and justifies the interest of the present study. This demonstrates how much women school heads, in this study; perform intentionally well, targeting the well-being of students that in turn likely foster their academic achievement. Through hidden talents and abilities these women leaders work hard to fulfil the needs of their schools by displaying diverse approaches to leadership such communicative, time regulators and problem-solving skills. By observing their behaviours and reflecting on their self-perception of leadership styles, these women confirmed how female leadership is constantly perceived in theory and in practice, including in the organizations. Indeed,women leaders are thought to be highly transformational leaders as found in some relevant studies of scholars like Eagly Eagly and Johanassen-Schmidt (2003), Bass, Avolio, and Atwater (1996), Bass, \& Riggio, (2006), Baudoux (1987). It is known that women leaders inspire, encourage and are supportive of their team workers. These factors influence learning and teaching, which likely improve the learning process of the students as well as their academic outcomes. In this study, findings revealed that women leaders are very much attached to the ethical values, which seem to reinforce their leadership as they used to pull up and motivate their staff members who seemed to appreciate their principals' styles of management. For example, WP7 expressed,

I attach great value to honesty and I am direct. I say what I think, with the right and worth words, even where other heads would not dare to do it. We must say what we think. (...) I used to tell my teachers to do the same thing as me, if they see flaws in my style or attitude, or if they have different opinions from mine. My way of being in my normal life is a reflection of my professional life. With my teachers, we work as a great team (...) and they enjoy working in a family-friendly climate.

\subsection{Major Issues Faced by Women Principals}

Based on the findings, women school heads experienced a number of hindrances and issues that they have to deal with. The interviewees' responses indicated that women in school leadership positions faced difficulties related to lack of resources and network, work-family roles conflict. Lack of confidence and decision-making issues, as well as structural factors, are also pointed out. Besides, social roles and gender stereotypes were not excluded from their difficulties.

\subsubsection{Social Roles and Gender Stereotypes}

As can be seen in table 2, women in school leadership positions faced hindrances related to various forms of issues, even though the most salient are the following: Negative attitudes of people and patriarchal leadership structure, tightly woven into social and roles and gender stereotypes. Lack of financial and material resources. Negative attitudes and cultural perceptions towards women and patriarchal attitudes that challenge most women. These two factors are tightly woven from social roles and gender stereotypes. However, these are not the only factors that affect women leaders in their headship. 


\subsubsection{Negative Attitudes and Cultural Perceptions Towards Women}

Negative attitudes of people and community (81\%) are also part of the problems facing women within the school. Indeed, people especially parents have less confidence in women in principalship due to the traditional culture. For a long time this profession was male-dominated and some of the parents rarely saw female leading school particularly in the rural areas, and that's why they sometimes display negative attitudes towards them. It happened sometimes that parents retained they kids at home or enter the classrooms to withdraw they children from school to the farm, especially the girls for housework. All those families' actions and reactions challenge female authority. Obviously, women are powerless in the face of such events. There is nothing women principals can do unless they decide to oppose, which may create confrontation or conflict within schools.

The negative attitudes are associated with social roles and gender stereotypes as noted $63.6 \%$ of participants. The social roles and stereotypes are embodied in the perception of women in Ivorian society. People believed that leading remains men exercise. This thought is more rigid in rural zones because people are strictly linked to tradition habitus that does not admit a female as a leader. That is why Domingo, Holmes, O’Neil, Jones, Bird, Larson, Presler-Marshhall, \& Valters $(2015$, p. 8$)$ pointed out that in many societies, women are (or have been) expected to remain silent in debate, denied the right of consent (to marital sex, to vote, over property) and seen as irrational or trivial. Undesirable attitudes towards women principals go along with disobedience from teachers, disrespect, and at times insults and offences from parents or visitors, especially men. Similarly, patriarchal attitudes very much concerned women in this study.

\subsubsection{Patriarchal Attitudes}

From the interviews, it came out that people still carry patriarchal leadership structure and mindset as shown by the $63.6 \%$ of respondents. Stereotypes related to women status is quite dominant in various types of professional sectors, be it rural or urban. Most cultural factors affect female in school leadership positions in sense that, as revealed participants, culture still reflects in the set of beliefs, values, customs and practices within their workplace, the populations and school communities as well. Because they have been cooperating with men principals for a long time, families and parents think that the school head is associated with men. Consequently, they expect and prefer to collaborate with men leaders. The finding is in agreement with Shava and Ndebele (2014) who asserted that to most men, a woman cannot be the head of an organisation unless in the absence of a man. Lindo (2012) found in her study that staff members in schools expected to see a male figure and work under the male headship. Women are much less likely than men to be considered leaders (Hill, Miller, Benson \& Handley, 2016).

Other examples of factors that affect women in their principal ship are sociocultural. Leila feels that "leadership is still considered the preserve of men. There are people who still think only men can be good leaders". This finding is in agreement with Coleman ( 2002) who reported that "the main gender-related problem for the women heads was the resentment felt by men and some women about women in a leadership role, the underlying belief that leadership is inappropriate for women"( p. 87). Women school heads in this study experienced resistance from their teachers, especially men teachers.

\subsubsection{Lack of Resources and Networking Issue}

The other hindrances reported by 9 female $(81 \%)$ was lack of resource. Since this school has been founded in 1958 (before the Independence, which is in 1960) none has been renovated. The teaching material, the infrastructure, the toilet, and walls are old, dilapidated and in poor condition. We do our best to repair as we can. There is no canteen for pupils who should eat safely. WP1 point out "There is no maintenance service for school property, lack of accommodation and money".

Since the tuition fee is free in elementary school in Cote d'Ivoire, the school relies only on the financial support that they annually expect even if it is not sufficient to cover all the school expenditure and needs. The community does not give any contribution either. So, you can imagine how the heads of school are struggling to manage, considering that situation.

WP11evoked an issue of networking that 8 (72.7\%) female mentioned, "Nowadays, in Côte d'Ivoire everything is done on the basis of relationship". .In endeavouring to provide good conditions for her pupils, she uses to visit embassies and philanthropists' NGOs and other private offices to look for help to build a canteen for students.

A female complained, "It's not easy to get help from the authorities, so I normally search ways or lobby to obtain donations from generous persons; my desire is to rehabilitate my school because since its foundation in 1958 it has never been renovated". WP9pointed out other issues, 'Today we are in a society where only relations and networking have some value. Faced with this reality, I am limited in my actions". It seemed that women do not have powerful relationship and network to get what they need to transform their school. According to Singh, Obe and Kumra, (2006) stated that networking refers to activities by individuals attempting to develop and maintain relationships with those 
with, or perceived to have, the potential to assist them in their work or career. That definition seems appropriate to the educational context, as networking is so important that any school leader cannot afford to lack it. Green (1982) mentioned that "successful networking can positively influence career outcomes such as increased job opportunities, job performance, income, promotions and career satisfaction, providing access to information, gaining visibility, career advice, social support, business leads, resources collaboration, strategy making, and professional support" (Green, 1982 as cited by Singh et al., 2006, p. 2). In their study, Singh et al. (2006) suggested that women and their employers appear to benefit strongly from being involved in corporate networking.

In the present study women principals were aware of the fact that networking is an important part of managerial behaviour and career success. That is why most of them tried to be open as possible to private organisations, the school community and the parents to gain from them suggestions, all kind of support, and assistance for transforming their schools. Opportunities for collegial support may have a positive impact on their school leadership roles (Parker, 2015).

\subsubsection{Being Powerless in Decision-Making}

This was revealed by $6(54,54 \%)$ of the women elementary school principals. This fact is due to two factors: within the school and from outside school. For instance, participant confirmed that leading people, especially male teachers within the school is not easy because some of them used to context or refuse to accept decisions just because they are made by women. That means teachers are at times uncooperative with the head of school. As revealed by the data, structural factors and their effects on women in principalship bring about serious issues and obstacles that these women experience and face the resistance from the members of school particularly male teachers who used to find unfounded excuses to defy the majority of decision and measures.

\subsubsection{Structural Factors Hurting Women}

In Côte d'Ivoire, men over number women in teaching profession. As woman, involving into the space of male-dominated profession might be quite difficult because the culture is still strongly patriarchal. Generally, the matter lies in the cultural beliefs of organizations. Burke (2015 raised the ambiguity of the situation of women in the academic field. Burke noted that women may outnumber men at university, though numbers alone will not change gender inequality. It can be argued that cultural prejudice, stereotypes, moral and psychological oppression remain the greatest perception of society, particularly from men in Ivorian context. For example, men happened to devise evil or do not easily accept to be run by a woman in school. In the mind of men, leadership is made for men, not for women. As said Msila, (2013, p. 464) "the man is always perceived superior by society irrespective of circumstances".

Cultural thoughts strengthen the misogyny of men towards women. This tends to assign systematically leadership to gender. Probably hat is why Trinidad and Normore (2004) underlined the importance of transcending the cultural norms to avoid a dangerous liaison that may come up between leadership and gender. These biases due to sexist stereotypes persist today, especially in rural areas. The attitudes and values associated with gender and leadership shape the beliefs and expectations of workplaces towards their members and stigmatize professional identity. Institutional barriers were also mentioned by female leaders, as they are not really sovereign and independent in making decisions. WP6 confirmed,

I am constantly being checked up to the extent that my power is limited as there some decisions I cannot take without notice or advice of the hierarchy. Humm, many decisions from top to down cannot be influenced nor reviewed instructions even though they do not fit the needs and the realities of the school and our context.

In fact, female school head has poor executive authority to make some serious decisions and implement adequate measures on educational subjects without consulting their hierarchy. It is one of the big issues as the Ivorian educational system has too many ramifications and is highly hierarchical. WP4 further reported, "We principals are powerless against that treatment as the authorities, stakeholders don't mind and most of parents and community ignore the realities we encounter the within school. This tends to be in line with Wandia (n,d) who revealed that women's voices are generally absent from the corridors and halls of power where important decisions that affect their lives are taken.

\subsubsection{Lack of Confidence}

These phenomena accentuate the lack of confidence (18.1\%) that women already have in themselves. In fact, two females acknowledge that having confidence in themselves constitutes a problem, "At times, we have not sufficient courage to take decision face some situations that I have never experienced or given me trouble. People, then take advantage of these weaknesses to continue to behave as they use to do. Studies mentioned lack of confidence as a common challenge to female leaders. For example, in their studies, Hlatywayo and Hlatywayo (2012), Hlatywayo, Hlatywayo \& Muranda (2014) and Sam, Amartei, Osei-Owusu and Antobre (2013) found that women administrators lack self-confidence or courage about expecting moving up in Zimbabwean Teachers Colleges. Also in the KPMG (2015)'s study it is suggested "to look at critically the challenges women often face, and clear the path for talented and 
dynamic leaders to rise to the top as confidence is an attribute that women themselves identify as the key to leadership success" ( p. 5). In fact, KPMG's survey revealed that $67 \%$ of women said they needed more support building confidence to feel like they can be leaders. This study stressed that the confidence, the encouragement of positive role models and the presence of a strong professional network shape a woman's view of leadership in the workplace.

\subsubsection{Work-Family Role Conflict}

In this study, the issue of balancing work responsibilities and family duties (36.3\%) is also a serious problem that the participants experienced in managing their school. Women participants admitted that they do not want to move away from their families. WP11 complained about her marital status. She said:

Sometimes, it is a burden to balance my school activities with family duties. I work every day without rest. I am both teacher and headmistress and since have divorced I am living only with my three kids.

WP10 leader expressed her difficulties. She explained how she has been struggling with fulfilling her home duties:

I divided my time between my work and my home, and consequently, I have very few times or no time to devote to my own needs. It is not easy to deal with the two types of responsibility-I have to take care of my children and my husband. Often when I get home late and my servant cooks, but my husband does not appreciate it, and he always complains. Unlike me, my husband has his own business, he is an entrepreneur, and thus he is his own boss. There is no pressure on him to accomplish a work or something. It is not easy to manage the house and the school. I get home in the evening very tired and I leave without good rest. All the day I handle individual and collective emotions at school and in the evening again, I have to care for my family. You cannot imagine how it hard to do that everyday.

Before getting headship position, WP10did not image she would encounter this kind of challenge. After a few months, she realised that the principalship is a complex job for her.

I have been teaching for more than ten years and I was interested in school headship position for my own promotion and personal reasons; I wanted to enhance my career and evaluate myself as someone who can lead, but now it is challenging me in the sense that I have to care of my children.

Indeed, WP10 wanted to try a new experience as head of school, that is to say, lead people within the school and test her skills. "I wanted to move up to high level, and evaluate myself". How to balance family charges/duties and work responsibilities concerned in a certain way female participants in this study. Grzywacz and Carlson (2007) defined work-family balance as the "accomplishment of role-related expectations that are negotiated and share between an individual and his or her role-related partners in the work and family domains" (p. 458).

The issue of balancing the personal life, children and work requirements is seen as the most common barrier that women face in headship. That is why some researchers (Kellerman \& Rhode, 2007) have found that women much time drop leadership roles and focus mainly on their family, which in turn disturb their professional career. From interviews, women principals have to balance a triple role: at home, in the community and in the workplace. In the context of Côte d'Ivoire, people expect from women first and foremost to be responsible for the family affairs and managing the home. These social roles attributed to women influence them and bring about pressure and stress in their principalship. For example, WP8 who decided to remain single after losing her husband to avoid the constraints of a married woman (house chores, conjugal duties, spouse needs)

I have decided not to contract a new marriage because I was afraid of not be able to integrate family and work life. You know it is hard to balance work and home duties, so I did not want to put myself under pressure because of heavy duties.

\section{Conclusion and Recommendations}

As shown in this study, in particular based on the teachers' perceptions and feelings, women principals are found to be supportive and effective leaders,. The most prominent tendency of leadership that these female leaders used is the transformative style that echoed in ethic manner. As the women leaders are known to be transformational individuals they would likely empower the students, especially those who have learning difficulties. Besides, this study highlighted that women educational leaders face hindrances in Ivorian schools and has pointed out that despite the appearances of quietude and peaceful environment within schools these women have to cope with many prejudices that still persist in Ivorian school settings.

The study found that obstacles faced by women school leaders embraced structural and socio-cultural entrenchments in Ivorian society and schools in particular. The study revealed that those stereotypes, cultural perceptions and other barriers these female leaders faced adversely affect their principalship and influence negatively their work.in some ways. In light of what the present study has shown, educational female leaders, however, possess certain hidden talents and 
natural competencies that need to be critically considered. Thus, beyond the multiple forms of hurdles, used to perform well by displaying transformational leadership style. In addition to being communicative, time regulators, good in problem-solving, the female principals who participated in this study, used to perform well in caring others and in practising collaborative style of leadership.

There is need to implement/reinforce affirmative action programmes towards women and work environment for women should be made more encouraging by introducing attractive systems to promote the participation of women in principalship and provide them with skills to enhance their inferiority complex and self-perception. Getting rid of stereotypes, cultural and structural biases against gender, and empowering women principals by giving them opportunities to help upgrade the overall students' academic outcomes, are the main recommendation for Ivorian educationist, policymakers, school boards and other stakeholders to respond to gender issues in educational leadership. Gender issues should be taught in the school to reduce gender stereotypes and empower teachers and students on gender matters. This may indirectly contribute to the education system improvement as well in Côte d'Ivoire. Thus, it is time to change the societal perceptions, minimize gender stereotypes and avoid unnecessary harmful prejudices. In addition, the school district should design effective forms of networking and mentor opportunities for women administrators.

Concerning the work-family balance, complementarity should be an option that husband and wife privilege in the couple, which would sustain the stability of their marriage. Besides, women need to maintain cohesion around them. Lastly, the educational policymakers and stakeholders must promote women in leadership positions for bridging the gap that existed between both genders. As such, women would get the opportunity to help upgrade the overall students' academic achievement, because any student regardless of his/her origin or background has the right to succeed according to the principle of equity, universally recognized.

\section{Acknowledgements}

The researcher expresses his utmost gratitude to his honorable Professor Zhang Lili whose guidance, support, and insights have been very helpful to this study. The author also appreciates the collaboration of the women participants.

\section{Reference}

Åkerlind, G. (2005b). Variation and commonality in phenomenographic research methods. Higher Education Research \& Development, 24(4), 321-334. https://doi.org/10.1080/07294360500284672

Akpaka, O. (2007). Analyse genre du programme de coopération Cote d'Ivoire UNICEF (2003-2007). Rapport Final. Retrieved January 15, 2016 from https://www.unicef.org/evaldatabase/files/ANALYSE_GENRE_R.Final_27.06.07.pdf

Al-Jarada, M. K. M., \& Zaid-Alkilani, K. K. (2015). Successful leadership practices in school problem-solving by the principals of the secondary schools in Irbid Educational Area. Review of European Studies, 7(3), 20-32. https://doi.org/10.5539/res.v7n3p20

Andela, C., Escandon, S. D., Garlo, C. K., \& Kamungi, P. M. (2008). Women of Africa Leadership Development Program Combined Research Report: Kenya, Liberia \& Côte d'Ivoire Research Period September 2007. October 2008. Retrieved on October 6, 2016

fromhttps://www.sfcg.org/programmes/lwi/documents/WomenOfAfrica_Liberia_IvoryCoast-FRENCH.pdf

Bass, B. M. (1985). Leadership and performance beyond expectation. New York: Free Press.

Bass, B. M. (1990). From transactional to transformational: Learning to share vision. Organizational Dynamics, 19 , 19-31. https://doi.org/10.1016/0090-2616(90)90061-S

Bass, B. M., \& Riggio, R. E. (2006). Transformational leadership. Mahwah, NJ: Laurence Erlbaum.

Bass, B. M., Avolio, B. J., \& Atwater, L.E. (1996). The transformational and transactional leadership of men and women. Applied Psychology: An International Review, 45(1), 5-34. https://doi.org/10.1111/j.1464-0597.1996.tb00847.x

Baudoux, C. (1987). Caractéristiques de gestion des directrices d'écoles secondaires. Revue des Sciences de l'Éducation, 13(3), 355-406. https://doi.org/10.7202/900572ar

Baudoux, C. (2002). Le leadership « féminin » en gestion de l'éducation. In L. Langlois et C. Lapointe (dir.), Le leadership en éducation. De multiples regards, une même passion. Montréal, Éditions La Chenelière/McGraw Hill: 49-74.

Bergeron, P. G. (2006). La gestion dynamique : concepts, méthodes et applications. (4è éd.). Montréal: Gaëtan Morin Éditeur.

Bernard, H. R. (2011). Research Methods in Anthropology. (5th ed.). AltaMira Press. 
Bogdan, R. C., \& Biklen, S. K. (1998). Qualitative research for education: An Introduction to theory and methods. (3rd ed.). Boston: Allyn and Bacon.

Brassard, A., Cloutier, M., De Saedeleer, S., Corriveau, L., Fortin, R., Gélinas, A., \& Savoie-Zajc, L. (2004). Rapport à l'activité éducative et identité professionnelle chez les directeurs d'établissement des ordres d'enseignement préscolaire et primaire. Revue des Sciences de l'Éducation, 30(3), 487-508. https://doi.org/10.7202/012079ar

Bryman, A. (2008). Social Research Methods. (3rd ed.). Oxford University Press.

Burke, P. J. (2015). Reducing gender equity to a battle of the sexes is simplistic, crude and dangerous. The Guardian. Retrieved March 30, 2016 from The Guardian website:

http://www.theguardian.com/commentisfree/2015/mar/08/gender-equity-battle-of-the-sexes-simplistic-crude-dange rous-universities

Conger, J. (1998). Qualitative research as the cornerstone methodology for understanding leadership. The Leadership Quarterly, 107-121. https://doi.org/10.1016/S1048-9843(98)90044-3

Creswell, J. W. (2012). Educational research: Planning, conducting, and evaluating quantitative and qualitative research. (3rd ed.). New Jersey: Pearson Education, Inc.

Domingo, P., Holmes, R., O’Neil, T., Jones, N., Bird, K., Larson, A., Presler-Marshhall, E., \& Valters, C. (2015). Women's voice and leadership in decision-making. Assessing the evidence. Report. Retrieved from https://www.odi.org/publications/9514-womens-voice-leadership-assessment-review-evidence

Dutercq, Y. (2006). Les nouveaux pouvoirs des chefs d'établissements. In G. Chapelle \& D. Meuret (Eds.), Améliorer l'école (pp. 141-152). Paris, France: Presses Universitaires de France.

Eagly, A. H. (2007). Women leadership advantage and disadvantage: Resolving thecontradictions. North Western University. Psychology of Women Quarterly, 31(1), 1-12. https://doi.org/10.1111/j.1471-6402.2007.00326.x

Eagly, A. H., Johannessen-Schmidt, M. C., \& van Engen, M. L. (2003). Transformational, transactional, and laissez-faire leadership styles: A meta- analysis comparing women and men. Psychological Bulletin, 129(4), 569591. https://doi.org/10.1037/0033-2909.129.4.569

Funk, K. D. ( 2015). Gendered Governing? Women's Leadership Styles and Participatory Institutions in Brazil. Political Research Quarterly, 68(3), 564-578. https://doi.org/10.1177/1065912915589130

Gartzia, L., \& van Engen, M. (2012). Are (male) leaders "feminine" enough?: Gendered traits of identity as mediators of sex differences in leadership styles. Gender in Management: An International Journal, 27(5), 296-314. https://doi.org/10.1108/17542411211252624

Gilligan, C. (1982). In a Different Voice: Psychological theory and Women's Development. Cambridge: Harvard university Press.

Growe and Montgomery (2000). Women and the leadership paradigm: Bridging the gender Gap. Retrieved August 3, 2017 from

https://www.researchgate.net/publication/242783132_Women_and_the_leadership_paradigm_bridging_the_gender _gap

Grzywacz, J. G., \& Carlson, D. S. (2007). Conceptualizing work-family balance: Implications for practice and research [Special edition]. Advances in Developing Human Resources, 9, 455-471. https://doi.org/10.1177/1523422307305487

Gupton, S. L. (2009). Women in Educational Leadership in the U.S.: Reflections of a 50 Year. Forum on Public Policy. Retrieved from https://files.eric.ed.gov/fulltext/EJ870094.pdf

Hallinger, P. (2008, March). Methodologies for studying school leadership: A review of 25 years of research using the principal instructional management rating scale. Paper presented at the annual meeting of the American Educational Research Association, New York, NJ. Retrieved February 18, 2016, from http://www.philiphallinger.com/papers/PIMRS_Methods_47.pdf

Hallinger, P., \& Heck, R. H. (1998). Exploring the principal's contribution to school effectiveness: 1980-1995. School Effectiveness and School Improvement, 9(2), 157-191. https://doi.org/10.1080/0924345980090203

Héon, L., Lapointe, C., \& Langlois, L. (2007). Réflexions méthodologiques sur le leadership des femmes et des hommes en éducation. Recherches Féministes, 20(1), 83-99. https://doi.org/10.7202/016117ar

Hill, C., Miller, K. Benson, K., \& Handley, G. (2016). Barriers and Bias. The status of women in leadership. AAUW Washington. Retrieved 2017, 30 July from http://www.ncgs.org/Pdfs/Resources/barriers-and-bias.pdf 
Hlatywayo, L., \& Hlatywayo, S. (2012). Challenges faced by female leaders at two Zimbabwean Teachers Colleges. International Journal of Science and Research, 3(8), 1444-1452. Retrieved 2017, 2 August from https://www.ijsr.net/archive/v3i8/MDIwMTU0Mzg=.pdf.

Hlatywayo, L., Hlatywayo, S., \& Muranda, Z. A. (2014). The Extent to which Females Occupy Leadership Positions in Zimbabwean Teachers Colleges. Journal of Humanities And Social Science 19(9), 28-36. Retrieved 2017, 2 August from https://doi.org/10.9790/0837-19972836

Kele, T., \& Pietersen, J. (2015). Women leaders in a South African higher education institution: Narrations of their leadership operations. OIDA International Journal of Sustainable Development, 8(5), 11-15. Retrieved December 13, 2017 from http://www.ssrn.com/link/OIDA-Intl-Journal-Sustainable-Dev.html

Kellerman, B., \& Rhode, D. L. (Eds). (2007). Women and leadership: The state of play and strategies for change. Foreword by Sandra Day O'CONNOR (Ret.). Jossey-Bass.

Kloot, L. (2004). Women and leadership in universities: a case study of women academic managers. International Journal of Public Sector Management, 17(6), 470-485. https://doi.org/10.1108/09513550410554760

KPMG (2015). KPMG Women's Leadership Study. Moving Women Forward into Leadership Roles. Retrieved June 20, 2017, from

https://womensleadership.kpmg.us/content/dam/kpmg-womens-leadershipgolf/womensleadershippressrelease/FIN AL\%20Womens\%20Leadership\%20v19.pdf

Leithwood, K. (Ed.). (2012, November). Leading Student Achievement: Networks for Learning (LSA) Real Stories: How LSA Participation Has Improved Leadership, Teaching and Student Achievement. (2nd Ed.). Retrieved 2016, May 21 from https://www.curriculum.org/LSA/files/LSA-Real-Stories.pdf

Lindo, C. A. (2012). Voices from the principalship: the experiences of five women who are principals in Jamaican primary and secondary schools. (Doctoral Thesis). University of Saskatchewan. Saskatoon.

Marks, H. M., \& Printy, S. M. (2003). Principal Leadership and School Performance: An Integration of Transformational and Instructional Leadership. Educational Administration Quarterly, 39(3), 370-397. https://doi.org/10.1177/0013161X03253412

Mberia, A. W. (2017). Women and leadership in mixed secondary schools in Kenya; do stakeholder's attitudes matter? International Journal of Social Science Research, 5(1). https://doi.org/10.5296/ijssr.v5i1.10157

Miles, M. B., \& Huberman, A. M. (2003). Analyse des données qualitatives. (2e éd.) Bruxelles : Édition De Boeck.

Mintzberg, H. (1990). Le management : Voyage au centre des organisations. Paris et Montréal : Éditions d'Organisation et Agence d'Arc.

MoE. (2017). Ministère de l'Éducation National. Données Statistiques de la Direction des Stratégies de la Planification et des Statistiques (DSPS). Availavble at http://www.men-dpes.org/new/index.php

Moreau, C. (2014). Rapport de la Côte d'Ivoire sur la mise en œuvre du programme d'action de Beijing vingt ans après. Ministère de la Solidarité, de la Famille, de la Femme et de l'Enfant. République de Côte d'Ivoire. Retrieved from https://www.uneca.org/sites/default/files/uploaded-documents/Beijing20/NationalReviews/cote_divoire_beijing_re view_report_0.pdf

Msila, V. (2013). Obstacles and Opportunities in Women School Leadership. International Journal of Educational Sciences. Retrieved July, 312017 from

https://www.academia.edu/4888503/Obstacles_and_Opportunities_in_Women_School_Leadership_A_Literature_ Study

Muzvidziwa, I. (2014). Principalship as an empowering leadership process: The experiences of women school heads in Zimbabwe. Anthropologist, 17(1), 213-221. https://doi.org/10.1080/09720073.2014.11891431

Palinkas, L. A., Horwitz, S. M., Green, C. A., Wisdom, J. P., Duan, N., \& Hoagwood, K. (2013). Purposeful Sampling for Qualitative Data Collection and Analysis in Mixed Method Implementation Research. In Administration and Policy in Mental Health and Mental Health Services Research, 42(5).

Parker, T. (2015). Secondary principals who are mothers: Balancing home and career. (Doctoral Dissertation). Walden University

Paustian-Underdahl, S. C., Walker, L. S., \& Woehr, D. J. (2014). Gender and perceptions of leadership effectiveness: A meta-analysis of contextual moderators. Journal of Applied Psychology, 99(6), 1129-1145.

https://doi.org/10.1037/a0036751 
Principal, School. (2002). In Encyclopedia of Education online. Retrieved March 16, 2018 from Encyclopedia.com: http://www.encyclopedia.com/education/encyclopedias-almanacs-transcripts-and-maps/principal-school

Riley, K. A., \& Louis, K. S. (Eds.). (2000). Leadership for change and school reform. Routledge, London. https://doi.org/10.4324/9780203465882

Sam, F. K, Amartei, A. M, Osei-Owusu, B., \& Antobre, O. O. (2013). Female leadership stereotypes: The perceptionof the leadership of female heads of senior high schools in Ashanti region. Educational Research, 4(10), 702-709. https://doi.org/10.14303/er.2013.229

Saunders, M., Lewis, P., \& Thornhill, A. (2012). Research methods for business students. (6th ed.): Harlow, England: Pearson Education.

Shakeshaft, C. (2006). Women and equity issues in educational administration and leadership. Presentation at 2006 annual meeting of American Educational Research Association. Retrieved https://soe.vcu.edu/files/2015/06/shakeshaft_cv.pdf

Shava, G. N., \& Ndebele, C. (2014). Challenges and opportunities for women in distance education management positions: Experiences from the Zimbabwe Open University (ZOU). Journal of Social Sciences, 40(3), 59-372. https://doi.org/10.1080/09718923.2014.11893331

Singh, V., Obe, S. V., \& Kumra, S. (2006). Women in formal corporate networks: organisational citizenship perspective. Forthcoming in women in management review.Retrieved July 25, 2017, from http://citeseerx.ist.psu.edu/viewdoc/download?doi=10.1.1.538.2894\&rep=rep1\&type=pdf

St-Germain, M. (2013). Analyse de la gestion dans les directions. Rapport de recherche (Étude des divergences entre le temps de travail réel et le temps de travail souhaité chez les directions membres de la FQDE /CHRA. Recherche-formation en gestion scolaire. Retrieved from http://fqde.qc.ca/wp-content/uploads/2014/02/Michel-St-Germain-version-abregee.pdf

Trinidad, C., \& Normore, A. H. (2005). Leadership and gender: a dangerous liaison? Leadership \& Organization Development Journal, 26(7), 574-590. https://doi.org/10.1108/01437730510624601

UN (2017). Social development for sustainable development. Transforming our world: the 2030 Agenda for sustainable development. Retrieved 2018, January 30 from

https://www.un.org/development/desa/socialperspectiveondevelopment/issues/sustainable-development.html

UNESCO (2002). Orientation, conseil et développement de la jeunesse pour l'Afrique participation de la femme à la vie publique. Direction-Gestion. Retrieved 2016, Jun 11 from http://unesdoc.unesco.org/images/0013/001386/138609f.pdf

Wandia, M. (n,d). Challenging Structural Inequities: The Vision of Feminist Transformative Leadership. Building Vibrant and Tolerant Democracies. A Journal on African Women's Experiences. Open Society Initiative for Southern Africa. Retrieved 2017, August 28 from http://www.osisa.org/sites/default/files/sup_files/Challenging\%20Structural\%20Inequalities-\%20the\%20vision\%2 0of\%20feminist\%20transformative\%20leadership\%20-\%20Mary\%20Wandia.pdf

\section{Copyrights}

Copyright for this article is retained by the author(s), with first publication rights granted to the journal.

This is an open-access article distributed under the terms and conditions of the Creative Commons Attribution license which permits unrestricted use, distribution, and reproduction in any medium, provided the original work is properly cited. 